Case report

\title{
Middle aged male with pulmonary tuberculosis and refractory hypercalcemia at a tertiary care centre in South East Asia: a case report
}

\author{
Azra Rizwan* and Najmul Islam
}

Address: Department of Medicine, Aga Khan University \& Hospital, Stadium Road, Karachi 74800, P.O. Box 3500, Pakistan

Email: AR* - azra.rizwan@aku.edu; NI - najmul.islam@aku.edu

* Corresponding author

Received: 3 March 2009 Accepted: 30 May 2009 Published: 6 July 2009

Cases Journal 2009, 2:6316 doi: 10.4076/1757-1626-2-6316

This article is available from: http://casesjournal.com/casesjournal/article/view/6316

(C) 2009 Rizwan and Islam; licensee Cases Network Ltd.

This is an Open Access article distributed under the terms of the Creative Commons Attribution License (http://creativecommons.org/licenses/by/3.0), which permits unrestricted use, distribution, and reproduction in any medium, provided the original work is properly cited.

\begin{abstract}
55-year male of Asian descent presented with weight loss, lethargy, drowsiness and low grade fever without cough. Examination revealed crackles in the chest but no focal neurological deficit. Chest $X$ ray revealed an infiltrate consistent with tuberculosis. Biopsy of infiltrate was negative for malignancy. Corrected calcium level revealed parathyroid independent hypercalcemia. Further diagnostic work up for drowsiness and hypercalcemia was normal. Despite receiving hydration and pharmacotherapy for his hypercalcemia, his condition failed to improve. When steroids were started, the patient's calcium levels and symptomatology resolved. Tuberculosis causing hypercalcemia is uncommon. Steroids are useful agents, particularly in refractory cases.
\end{abstract}

\section{Introduction}

Hypercalcemia has long been known to be associated with tuberculosis, with a recent increase in its occurrence possibly related to widespread accessibility to diagnostic testing $[1,2]$. Generally speaking, the hypercalcemia is mild and asymptomatic [2,3]. We aim to describe a case of a middle-aged gentleman with refractory hypercalcemia associated with tuberculosis of the lungs.

\section{Case presentation}

This is a description of a 55-year-old male, banker by profession and of Asian descent, an Urdu speaking Pakistani. He was a long-standing smoker, having smoked
3 packs per day for 30 years prior to presentation. He denied any form of alcohol intake and had been found to have type 2 diabetes 17 years prior to presentation. There was no known history of tuberculosis or any form of calcium disorder in parents, siblings or children. He weighed $47 \mathrm{~kg}$ and was $1.65 \mathrm{mt}$ tall.

He presented in December 2007 with a 6-month history of unplanned weight loss, of up to $13 \mathrm{~kg}$, associated with recent onset weakness and drowsiness, low grade fever but no cough. Clinical examination revealed a normotensive, lean individual, with crackles in his left upper chest but no focal neurological deficit. 
An X- ray of his chest revealed a left lingular infiltrate. Brochoalveolar lavage produced a smear positive and culture positive tuberculosis that was pan sensitive. Biopsy of the infiltrate was negative for malignancy.

His serum calcium level was high, (Table 1), with the initial corrected calcium level at $13.2 \mathrm{mg} / \mathrm{dl}$ and a low parathormone level, with normal 25-OH Vitamin D levels and a high 24 hour urine calcium. His serum phosphate was normal. A diagnostic work up for drowsiness and hypercalcemia, (Table 2), revealed a normal serum sodium. Serum magnesium was initially low and was corrected to a normal level. Thyroid function tests were initially consistent with hyperthyroidism, with the thyroid scan showing negligible uptake. They subsequently normalized within 4 weeks. Serum protein electrophoresis, liver function tests, angiotensin converting enzyme (ACE) levels and a morning cortisol level were normal.

MRI brain was negative for tuberculomas. CSF $D / R$ revealed a high protein content, while routine and AFB cultures of the CSF were negative. Vasculitic work up was negative.

Hence, a diagnosis of hypercalcemia secondary to pulmonary tuberculosis was made.

The patient was hydrated aggressively, followed by diuresis with intravenous furosemide, $40 \mathrm{mg}$, once the patient had been well hydrated. Intravenous pamidronate $90 \mathrm{mg}$ was administered twice over a period of two months, as well as daily calcitonin injections at 240 IU subcutaneously twice daily. A nephrology consult revealed that dialysis was not feasible because of non availability of a calcium free dialysate. Subsequently, steroids were started at $40 \mathrm{mg} /$ day, while his anti tuberculous medication was continued, including isoniazid $300 \mathrm{mg}$, rifampicin $600 \mathrm{mg}$, ethambutol 1200 mg, pyrazinamide 1500 mg per day.

Serum calcium fluctuated between 12.0 - 14.2 for a period of two and a half months and his drowsiness, disorientation \& hypercalcemia failed to resolve with the initial measures. Once steroids were started, the calcium levels

Table I. Initial Investigations

\begin{tabular}{lcc}
\hline $\begin{array}{l}\text { Chest } \times \text { ray } \\
\text { Broncho-alveolar } \\
\text { lavage }\end{array}$ & $\begin{array}{l}\text { Left Lingular Infiltrate } \\
\text { Smear Positive and Culture Positive } \\
\text { Biopsy of infiltrate } \\
\text { Tuberculosis- Pansensitive } \\
\text { Negative for Malignancy } \\
\text { Patient Result }\end{array}$ & $\begin{array}{c}\text { Normal Range } \\
8.6-10.5\end{array}$ \\
$\begin{array}{l}\text { Initial corrected } \\
\text { calcium level }\end{array}$ & 13.2 & $16-87$ \\
$\begin{array}{l}\text { Parathormone level } \\
25 \text { OH vitamin D }\end{array}$ & 7.76 & $>30$ \\
24 hour urine & 34.5 & $100-300$ \\
calcium & 302 & \\
\hline
\end{tabular}

Table 2. Diagnostic work up for drowsiness and hypercalcemia

\begin{tabular}{|c|c|c|}
\hline & Patient Result & Normal Range \\
\hline Serum sodium & 137 & $136-146$ \\
\hline Serum magnesium & 1.4 & $1.9-2.5$ \\
\hline $\begin{array}{l}\text { Serum magnesium after } \\
\text { correction }\end{array}$ & 2.1 & $1.9-2.5$ \\
\hline \multicolumn{3}{|l|}{ Thyroid function tests } \\
\hline TSH & 1.18 & $0.27-4.2$ \\
\hline \multirow[t]{2}{*}{ FT4 } & 1.65 & $0.93-1.7$ \\
\hline & Patient Result & Normal Range \\
\hline \multicolumn{3}{|l|}{$\begin{array}{l}\text { SerumProtein } \\
\text { Electrophoresis }\end{array}$} \\
\hline Total Protein & $5.80 \mathrm{~g} / \mathrm{dl}$ & $5.7-7.75$ \\
\hline Albumin & $2.93 \mathrm{~g} / \mathrm{dl}$ & $3.5-4.0$ \\
\hline Gamma & $1.17 \mathrm{~g} / \mathrm{dl}$ & $0.71-1.45$ \\
\hline \multicolumn{3}{|l|}{ Liver Function Tests } \\
\hline SGPT & 14 & $0-55$ \\
\hline Alkaline Phosphatase & 82 & $28-124$ \\
\hline ACE Level & 10 & $8.0-52.0$ \\
\hline Serum AM Cortisol & $34.90 \mathrm{ug} / \mathrm{dl}$ & $4.2-38.4$ \\
\hline Serum Phosphate & $3.1 \mathrm{mg} / \mathrm{dl}$ & $2.7-4.8$ \\
\hline CSF D/R & $200 \mathrm{mg} / \mathrm{dl}$ & $15-45$ \\
\hline \multicolumn{3}{|l|}{ Vasculitic Work Up } \\
\hline ANA & Negative & \\
\hline ASMA & Negative & \\
\hline AMA & Negative & \\
\hline MRI Brain & No Tuberculomas & \\
\hline
\end{tabular}

gradually began to resolve (Figure 1), as did the patient's confusional status.

\section{Discussion}

Primary hyperparathyroidism and malignancy remain the most common etiologies of hypercalcemia, accounting for $90 \%$ of all cases [2]. Chronic granulomatous disease is well known to cause hypercalcemia $[1,4]$. Tuberculosis and fungal infections are subtypes of chronic granulomatous disease that are more prevalent in the developing

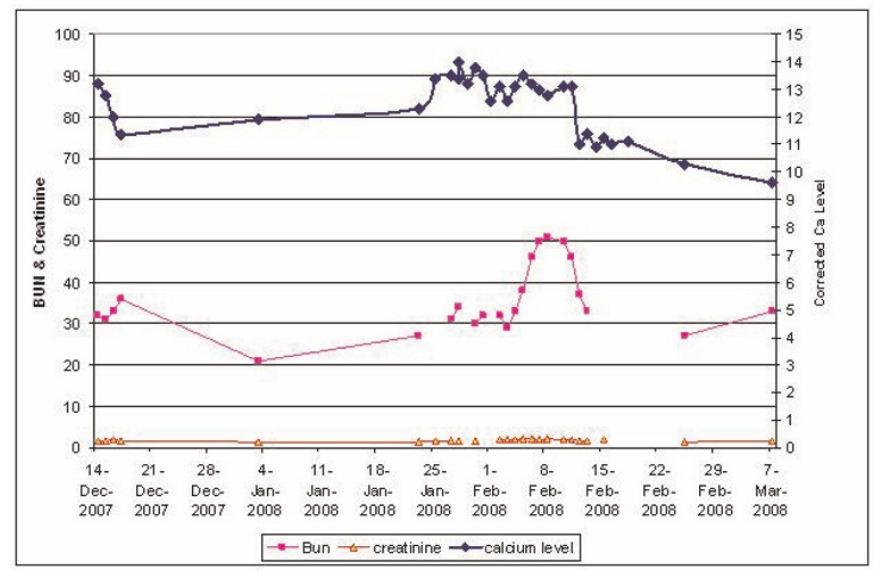

Figure I. Graph showing the serial changes in blood levels of calcium, creatinine and bun. 
countries $[1,4]$, or the immunocompromised individuals across the globe [5-8]. Sarcoidosis is a form of chronic granulomatous disease seen more commonly in Caucasians [9]. These entities need to be considered in the differentials, in the appropriate context. Chronic granulomatous disease is associated with a parathyroid independent hypercalcemia, resulting from the 1,25 dihydroxyvitamin D producing granulomas. The non availability of the 1,25 dihydroxyvitamin D level precluded us from ordering the test, a limitation of the report because it is high levels of this biochemical marker that would have helped to confirm the etiology.

Our patient did exhibit a transient thyroiditis, as evidenced by the negligible uptake on thyroid scan. Thyroiditis has been documented in the literature to be associated with tuberculosis [10], with the hypercalcemia resulting from the hyperthyroidism. However, the calcium levels had remained elevated despite resolution of the thyroiditis. Other causes such as adrenal insufficiency, multiple myeloma and sarcoidosis that may have additionally contributed were essentially ruled out through a normal morning cortisol, serum protein electrophoresis and ACE levels, respectively. There had been no history of recent ingestion of antacids, vitamin A, D or calcium supplements, nor had there been any reported use of thiazide diuretics or lithium.

Tuberculosis causing hypercalcemia is an uncommon but well recognized phenomenon, particularly in the Asian subcontinent where concomitant vitamin D deficiency makes the occurrence even less likely [11-13]. This degree of symptomatic hypercalcemia is even rarer [14], which in this patient manifested as prolonged alteration in mentation. In most cases, the hypercalcemia responds to simple conventional measures of hydration and diuresis [15]. Dialysis is recommended in resistant cases but could not be availed due to the current non availability in our unit of a calcium free dialysate. Steroids are useful agents to use, particularly in refractory cases, where they act through their anti inflammatory effects on the vitamin D producing granulomas \& through inhibition of the one alfa hydroxylase enzyme that converts $25 \mathrm{OH}$ vitamin $\mathrm{D}$ to 1,25 Dihydroxyvitamin D [15].

\section{Conclusion}

Knowledge of the association between tuberculosis and hypercalcemia, plus its mechanism of action is important in order to correct the symtomatology resulting from elevated calcium levels. Steroid therapy needs to be instituted early in cases of hypercalcemia complicating tuberculosis.

\section{Abbreviations}

25-OH vitamin D, 25 hydroxyvitamin D; ACE, Angiotensin Converting Enzyme; MRI, Magnetic Resonance Imaging; CSF D/R, Cerebrospinal Fluid Detailed Report; AFB, Acid Fast Bacilli.

\section{Consent}

Written informed consent was obtained from the patient for publication of this case report and accompanying tables and figures. A copy of the written consent is available for review by the Editor-in-Chief of this journal.

\section{Competing interests}

The authors declare that they have no competing interests.

\section{Authors' contributions}

NI was the Attending under whose care the patient had remained admitted. He reviewed and approved the final manuscript. AR was the Fellow to whom the patient was assigned and played a major role in writing the manuscript. Both authors read and approved the final manuscript.

\section{References}

I. Abbasi AA, Chemplavil JK, Farah S, Muller BF, Arnstein AR: Hypercalcemia in active pulmonary tuberculosis. Ann Intern Med 1979, 90:324-328.

2. Jacobs TP, Bilezikian JP: Clinical review: Rare causes of hypercalcemia. J Clin Endocrinol Metab 2005, 90:6316-6322.

3. Yotsumoto H: Fever, hypercalcemia and tuberculosis. Intern Med 2007, 46:259-260.

4. Abal AT, Jayakrishnan B, Parwer S, El Shamy AS, Khadadah M, Ayed A, Alawi AA: Demographic pattern and clinical characteristics of patients with smear- positive pulmonary tuberculosis in kuwait. Med Princ Pract 2005, I 4:306-3I2.

5. Bell NH, Shary J, Shaw S, Turner RT: Hypercalcemia associated with increased circulating 1,25 dihydroxyvitamin $D$ in a patient with pulmonary tuberculosis. Calcif Tissue Int 1985, 37:588-59l.

6. Sullivan JN, Salmon WD Jr: Hypercalcemia in active pulmonary tuberculosis. South Med J 1987, 80:572-576.

7. Meuthen I, Kirsch L, Saborowski F: Hypercalcemia in florid pulmonary and cervical lymph node tuberculosis. Dtsch Med Wochenschr 1991, I 16:899-902.

8. Ferrand RA, Elgalib A, Newsholme W, Childerhouse A, Edwards SG, Miller RF: Hypercalcaemia complicating immune reconstitution in an HIV-infected patient with disseminated tuberculosis. Int J STD AIDS 2006, I 7:349-350.

9. Winnacker JL, Becker KL, Katz S: Endocrine aspects of sarcoidosis. N Engl J Med 1968, 278:483-492.

10. Simkus A: Thyroid tuberculosis. Medicina (Kaunas) 2004, 40:201204.

II. Howe WR, Dellavalle R: Vitamin D deficiency. N Engl J Med 2007, 357:1981.

12. Bouillon R, Norman AW, Lips P: Vitamin D deficiency. N Engl J Med 2007, 357:1980-198I.

I3. Holick MF: Vitamin D deficiency. N Engl J Med 2007, 357:266-28I.

14. Dosumu EA, Momoh JA: Hypercalcemia in patients with newly diagnosed tuberculosis in Abuja, Nigeria. Can Respir J 2006, 13:83-87.

15. Hutton E: Evaluation and management of hypercalcemia. JAAPA 2005, I 8:30-35. 